\title{
The bankruptcy prediction approach: An empirical study of comparison between the emerging market score model and bankruptcy prediction indicators approach in the Johannesburg Stock Exchange
}

\begin{tabular}{|c|c|}
\hline \multicolumn{2}{|c|}{$\begin{array}{l}\text { Authors: } \\
\text { Ronel J. Cassim }{ }^{1} \text { ๑ } \\
\text { Matthys J. Swanepoel }{ }^{2} \text { ๑ }\end{array}$} \\
\hline \multicolumn{2}{|c|}{$\begin{array}{l}\text { Affiliations: } \\
\text { 'Department of Accountancy, } \\
\text { Faculty of Management } \\
\text { Sciences, Vaal University of } \\
\text { Technology, Vanderbijlpark, } \\
\text { South Africa }\end{array}$} \\
\hline \multicolumn{2}{|c|}{$\begin{array}{l}{ }^{2} \text { Department of Accountancy, } \\
\text { Faculty of Economic and } \\
\text { Management Sciences, } \\
\text { North-West University, } \\
\text { Vanderbijlpark, South Africa }\end{array}$} \\
\hline \multicolumn{2}{|c|}{$\begin{array}{l}\text { Corresponding author: } \\
\text { Ronel Cassim, } \\
\text { rcassim28@gmail.com }\end{array}$} \\
\hline \multicolumn{2}{|c|}{$\begin{array}{l}\text { Dates: } \\
\text { Received: } 26 \text { Nov. } 2019 \\
\text { Accepted: } 19 \text { Nov. } 2020 \\
\text { Published: } 29 \text { Jan. } 2021\end{array}$} \\
\hline \multicolumn{2}{|c|}{$\begin{array}{l}\text { How to cite this article: } \\
\text { Cassim, R.J. \& Swanepoel, } \\
\text { M.J., 2021, 'The bankruptcy } \\
\text { prediction approach: An } \\
\text { empirical study of comparison } \\
\text { between the emerging market } \\
\text { score model and bankruptcy } \\
\text { prediction indicators } \\
\text { approach in the Johannesburg } \\
\text { Stock Exchange', Journal of } \\
\text { Economic and Financial } \\
\text { Sciences } 14(1) \text {, a539. https:// } \\
\text { doi.org/10.4102/jef.v14i1.539 }\end{array}$} \\
\hline \multicolumn{2}{|c|}{$\begin{array}{l}\text { Copyright: } \\
\text { ( ) 2021. The Authors. } \\
\text { Licensee: AOSIS. This w } \\
\text { is licensed under the } \\
\text { Creative Commons } \\
\text { Attribution License. }\end{array}$} \\
\hline \multicolumn{2}{|l|}{ Read online: } \\
\hline 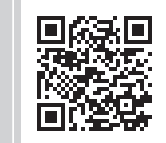 & $\begin{array}{l}\text { Scan this QR } \\
\text { code with your } \\
\text { smart phone or } \\
\text { mobile device } \\
\text { to read online. }\end{array}$ \\
\hline
\end{tabular}

Orientation: The effective and timely bankruptcy prediction is crucial to the survival of companies. In order to attain a desired result an effective bankruptcy prediction tool needs to be applied within a South African context.

Research purpose: The aim of this study was to determine whether bankruptcy could have been predicted within the 5 years prior to failure for the study period between 2016 and 2018 .

Motivation for the study: Most of the bankruptcy prediction studies in South Africa are industry- or sector-based, not many studies are found to be generic, easy to use and apply, and thus one model is applied for different industries or sectors.

Research approach/design and method: From the population, the total sample consists of five companies within four different sectors, such as industrial, construction, retail, and personal and household sectors. Financial indicators (financial ratios) were obtained for both the BPIA and EMS from the INET (a South African supplier of quality financial data) McGregor BFA database, a JSE portal. A mixed-method research approach was applied by making use of a qualitative and quantitative methodology.

Main findings: The findings revealed that the BPIA is an effective and reliable analytical tool to predict or detect the bankruptcy of South African companies.

Practical/managerial implications: Based on the finding of the study companies within diverse industries should apply the BPIA regularly and take remedial action significantly to improve their financial well-being.

Contribution/value add: The study has identified the BPIA has a better prediction accuracy than the renowned EMS model in South African context.

Keywords: bankruptcy prediction indicator approach; bankruptcy; company failure; emerging market score model approach; financial distress; South African context.

\section{Introduction}

The cost of company failure has significant results and many casualties, which include not only the failed companies that are affected but also their stakeholders. Cassim (2015) and Tuvadaratragool (2013) identified some of the stakeholders such as banks, creditors, employees and governments. Because of the stakeholders being affected by financial distress, it is important to consider the phenomenon of early warning signs or detect company's financial failure (Sabela et al. 2018). In recent times, great industry giants such as Lehman Brothers, American International Group (AIG), Chrysler in the United States and Nationwide Airlines, Velvet Sky and 1Time Holdings in South Africa have succumbed to company failure (Ngwenya 2018; Purves \& Niblock 2018).

According to Ngwenya (2018), financial failure may be a result of financial distress that has not been relieved timely, and ultimately, it could take on a form of bankruptcy. Charitou, Neophytou and Charalambous (2004) explained that company failure is due to different factors such as interest rates, recession-squeezed profit, operating nature and government regulations. Companies still use financial ratio analysis as a management tool within various bankruptcy prediction models despite extensive changes in technology over the years. These ratios utilised within the financial ratio analysis have been established since the 1930s (Bellovary, Giacomino \& Akers 2007). Houghton and 
Woodliff (1987) described that various seminal studies within the field of study have indicated financial ratios being useful predictors of failure or success and are the cornerstone of bankruptcy prediction models (Altman 1968; Beaver 1966). Up to now, researchers mainly use financial ratio analysis in bankruptcy prediction modelling. The problem is different models use different financial ratios, which are sector-based and paired to their peers within the industry (Purves \& Niblock 2018). Russell, Langemeier and Briggman (2013) suggested that organisational success is determined by applying financial performance ratios. These financial performance ratios were obtained from a company's financial statements and have been examined to identify the causes of failure by several prediction studies (Beaver, McNichols \& Rhie 2005; Ciampi 2015).

To the best of our knowledge, so far, there have not been many studies conducted as a cross-comparative study. To date, researchers have mainly used models that were industry- or sector-based. This study investigates the ability of a generic bankruptcy prediction indicators approach (BPIA) to detect or predict the financial distress within different industries or sectors. Companies within different industries or sectors have problem is that different industries or sectors have different lifespans, and it is important in this study to detect or predict the early warning signs of financial distress or failure (Garelli 2016).

The purpose of this study was to empirically compare the results of two alternative approaches, the emerging market score (EMS) model approach and BPIA within a South African context. The EMS model is a sophisticated, recognised, prominent ratio-based analytical tool used to evaluate and assess non-manufacturing industries and companies within emerging markets (Altman 2018). According to Tuvadaratragool (2013), the EMS model is the first to assess a company's financial health within emerging markets consisting of four variables: financial indicators, working capital to total assets (WC/TAs), retained earnings to total assets (REs/TAs), earnings before interest and tax to total assets (EBIT/TAs), and books value of equity to total liabilities (BVE/TL). This model acts as a benchmark for the bankruptcy prediction of emerging markets. The BPIA also consists of five variables, financial indicators that have been selected statistically.

In order to satisfy this purpose, firstly, a literature study was carried out to investigate the EMS model and BPIA as benchmarking models. Furthermore, an empirical investigation on South African delisted companies was executed in order to determine the ability of the model to detect or predict financial distress within 5 years prior to their financial unhealthy status being made public.

\section{Literature review}

A study's background is established through the literature review. Bless, Higson-Smith and Sithole (2013) described literature review as the drive to gain first-hand knowledge of what has been studied within a particular field of study. Harmse (2017) suggested gathering background information to help the researcher to understand the phenomenon under investigation. The findings by Gouws and Lucouw (1999) indicated that when financial data are transformed and expressed into ratios, an understanding is gained because these ratios can then be compared with other ratios. This is known as financial ratio analysis.

Purves and Niblock (2018) explained that financial ratios applied in financial ratio analysis data are obtained from a company's financial statements (statement of financial position, statement of comprehensive income and statement of cash flow). However, there were concerns when applying the accuracy of accounting information, which are given as follows:

- Difference in the accounting standards internationally, and this concern was overcome by applying this study within a South African context.

- The preparation, presentation and interpretation could be misleading and, in turn, compromise the financial analysis. This was overcome by excluding the financial industry and mining sector as these industries and sectors are highly regulated and because of their differences in asset and profit structure. Therefore, the sample was selected from the remaining industries based on the selected criteria (Hlahla 2010; Rama 2012).

- The last and final concern according to literature, when financial ratios are used as failure prediction tools it needs to be sector specific (Altman 2002; Madrid-Guijarro, García-Pérez-de-Lema \& Van Auken 2011). The objective of the generic BPIA is to predict timely financial distress in comparison with the legendary EMS model.

The EMS model was developed from the Altman's z-score model. It is the latest modified and adapted version to make it more versatile to different companies within different industries and economies, with the aim of improving the accuracy by changing the focus from publicly listed manufacturing industries to emerging markets. The EMS model was enhanced by changing the variables (financial ratios) from five variables to four; in addition, the weighting factor (coefficients) and cut-off zone were changed (Altman 1993). The overall index is obtained by multiplying the variable (financial ratios) by the weighting factor (coefficients), resulting in the overall index that indicated in which zone the company is represented. Altman and Hotchkiss (2010:280) applied this model to countries with emerging markets from Argentina to Mexico, including Asian countries with remarkable bankruptcy prediction results. The changes are illustrated in Table 1.

As shown in Table 1 when the cut-off zone is $>2.60$, it illustrates a company as being in the safe zone (unlikely to experience financial failure). Followed by the grey zone when the overall index is $>1.10<2.60$, it is representative of caution (zone of uncertainty) as the company could be uncertain whether it will experience financial failure or not. Finally, it is in the distress zone when the overall index is 
TABLE 1: Evolving of $z$-score to emerging market score model.

\begin{tabular}{lll}
\hline Model & $z$-score & EMS \\
\hline Date & 1968 & 2006 \\
Variables & WC/TA & WC: TA \\
& RE/TA & RE: TA \\
& EBIT/TA & EBIT/TA \\
& BV equity: TL & BV equity: TL \\
& Sales: TA & - \\
Coefficients & $1.2_{x 1}$ & 3.25 \\
& $1.4_{x 2}$ & $6.56_{\times 1}$ \\
& $3.3_{x 3}$ & $3.26_{x 2}$ \\
& $0.6_{x 4}$ & $6.72_{x 3}$ \\
Cut-off zones & $1.0_{x 5}$ & $1.05_{x 4}$ \\
& Safe: $Z>2.99$ & Safe: $Z>2.60$ \\
& Grey: $1.81<Z<2.99$ & Grey: $1.1<Z<2.60$ \\
& Distress: $Z<1.81$ & Distress: $Z<1.1$ \\
\hline
\end{tabular}

Source: Altman, E.I., 2002, 'The use of credit scoring models and the importance of a credit culture', linha, viewed 15 September 2011, from https://people.stern.nyu.edu/ealtman/ Presentations.html

WC/TA, working capital to total assets; RE/TA, retained earnings to total assets; EBIT/TA, earnings before interest and tax to total assets.

\section{TABLE 2: Safe zone.}

\begin{tabular}{lccccc}
\hline Ratio & ROE & ROA & EBIT/TA & TATO & CF/TD \\
\hline Safe zone & 18.76 & 13.91 & $5 \times$ & 1.90 & 33.16 \\
\hline
\end{tabular}

Source: Cassim (2020)

ROE, return on equity; ROA, return on assets; EBIT/TA, earnings before interest and tax to total assets; TATO, total asset turnover; CF/TD, cash flow to total debt.

$<1.10$, which represents a company is likely to fail financially (Cassim 2020).

The BPIA is a newly developed bankruptcy prediction model that works similar to the Altman EMS model. The model statistically determined five variables (financial ratios) to predict a safe zone. Unlike the overall index that has to be computed in the EMS model, the safe zones for the BPIA have been determined individually per variable (Table 2). The BPIA was developed from a South African perspective and sample consisted of Johannesburg Stock Exchange (JSE) listed companies, the largest stock exchange in Africa and 19th largest in the world. The JSE was founded on 8 November 1887 by Benjamin Woollan. Currently, 10 industries are listed on the JSE, 20 sectors and 35 subsectors operate within these industries and 727 companies function within these sectors (Cassim 2020). According to Asuelime (2018), South Africa became the fifth member of the Brazil, Russia, India, China and South Africa (BRICS) in 2010. Being a member to this elite club, South Africa's chances of free or easy trade were increased with the other BRICS members and developing countries.

The EMS model has been applied to Enron and Worldcom industrial giants, and the test concluded that both Enron and Worldcom' EMS ranked beneath the safe zone prior to their bankruptcy filing (Altman and Hotchkiss 2010). The EMS model has also been applied successfully in BRICS countries by various researchers. Altman and Hotchkiss (2010) concluded that the EMS model is particularly robust in countries like Brazil, whilst Coelho (2014) agreed that it is accurate and useful for the Brazilian economy. Vasantha, Vasantha and Thiayalnayaki (2013) argued that the EMS model accurately determines the financial soundness of Indian companies under review.

Correia et al. (2015) agreed with Tuvadaratragool (2013) that the EMS model is a well-known superior bankruptcy prediction model and a ratio-based model with a proven track record in failure prediction for companies within emerging markets, and this is the rationale for selecting the EMS model approach as authentication and validation of the BPIA, a newly developed model with a South African perspective.

\section{Methodology}

This study is empirical in nature using secondary data, with a combination of both numeric and textual data (Mouton 2011). An exploratory design with a mixed-method approach is applied. The mixed-method approach is a combination of both quantitative (numeric) and qualitative (textual) methods (Maree 2020). Creswell (2014:220) explained that exploratory design is adopted 'when qualitative data builds up to quantitative data and the interpretation commences from a qualitative point followed by a quantitative point'. Zikmund et al. (2013) explained that exploratory design is applied when the aim is to clarify vague situations. The mixed method concurrently uses the qualitative and quantitative research methods (Schwester 2015).

The target population for this study is JSE companies that have not necessarily failed but are facing great financial difficulties and have been delisted from the JSE after 2016, excluding the financial industry and mining sector, because of structural differences. The sample was selected out of a population of three different industries, industrial, consumer goods and consumer services, and the five companies that were selected and operated within four different sectors: industrial, construction, retail, and personal and household. The sample selection was not based on random selection, but rather on availability, convenience and selection criteria, as the researcher had easy access to the secondary, audited, reliable and publicly available data (Saunders 2016). The selection criteria only included companies that failed or that were facing financial difficulties during the period 20162018. The sample was selected from the selection criteria, and data were conveniently accessible, making this a convenient quota sampling technique. Data were collected 5 years prior to facing financial difficulties from the INET McGregor BFA database (2018), a reputable JSE portal (Harmse 2017).

After the sample selection, the ratios applied in the BPIA and the EMS model approach were extracted. The BPIA was developed by applying statistical testing. A descriptive statistical test was performed, only five of the nine bankruptcy prediction indicators were found to possess statistical significance. The nine financial ratios were selected based on the study by Cassim (2015), which outlines the four pillars of a company's financial health. The first pillar, the profit potential, indicates the adequate utilisation of company assets and equity in generating returns. Ratios included in 
this pillar are the return on equity (ROE), return on assets (ROA) and total asset turnover (TATO). The second pillar, financial stability, is represented by the quick ratio $(\mathrm{QR})$ and cash flow to total debt (CF/TD). The QR was used as it eliminates any chances of obsolete inventory being included in liquidity computation unlike the current ratio. Cash flow is important because when a company has inadequate funds, they cannot proceed, which seems to be a growing concern. The third pillar is growth potential, demonstrating whether the company's sales and earnings are growing and is represented by the sales growth and earnings growth ratios. The risk being the fourth pillar, which indicates whether the company can at least repay the interest commitments, signified by the debt ratio (DT) and interest cover (EBIT/ TA/I) (Cassim 2015).

The descriptive statistical test, firstly, applied the Kolmogorov-Smirnov (K-S) test to determine whether the data were normally distributed, followed by a non-parametric Mann-Whitney test as the $(\mathrm{K}-\mathrm{S})$ test indicated the nonnormality of the population (Pallant 2016). The results from the interpretation showed that the Mann-Whitney test and the descriptive test were similar regarding statistical significance and indicated that five of the nine ratios selected for the BPIA were statistically significant, with $p$-values of $<0.01$. According to Pallant (2016), $p$-values of $<0.01$ and $<0.05$ are considered to be statistically significant, with the ratios being ROA, ROE and interest cover (EBIT/TA), TATO ratio and $\mathrm{CF} / \mathrm{TD}$.

The bankruptcy indicators were tested on two levels. The ROA, ROE and interest cover expressed as EBIT/TA were tested at the first level. These bankruptcy indicators are the statement of comprehensive income (SOCI), level 1 testing being the survival level indicators. The second level is the TATO and CF/TD expressed as bankruptcy indicators, it gives the statement of financial position (SFP) and this is level 2 and is referred to as the thriving level.

The following companies have been selected to be tested: Howden Africa (HWN) (industrial: general), Edgars Consolidated Stores (ECO) (consumer: retail sector), Basil Read (BSR) (industrial: construction sector), Steinhoff International Holding (SNH) (consumer: retail sector) and Group Five Holding (GHO) (industrial construction sector). The safe zone for bankruptcy prediction indicators is illustrated in Table 2, and the EMS model is displayed in Table 1 (refer to Literature Review).

Table 2 displays the recommended ratio. Below the indicated amount is referred to as the distress zone, and above the indicated amount is referred to as the recommended zone. The years prior to failure are indicated as follows: $\mathrm{Y} 1$ represents 5 years prior to failure, $\mathrm{Y} 2$ represents 4 years prior to failure, $\mathrm{Y} 3$ represents 3 years prior to failure, $\mathrm{Y} 4$ represents 2 years prior to failure and $\mathrm{Y} 5$ represents 1 year prior to failure.

\section{Ethical considerations}

Ethical clearance was issued by the North-West University in 2016 with the ethical clearance number: ECONIT-2016-035.

\section{Results}

Testing of the companies commenced, and Table 3 depicts the evaluation of Howden Africa Holding Ltd by applying the EMS model.

The EMS model is for five consecutive years and is exemplified as safe attesting to a strong credit profile as per bond rate, as shown in Table 3. When a company is within the safe zone it indicates companies are not exposed to financial distress. Upon when within this zone as it indicates the companies are not exposed to financial distress. The BPIA of Howden Africa Holding Ltd. (HWN) is shown in Table 4.

According to Table 4, the bankruptcy indicators for HWN highlight no concerns at first glance but in $\mathrm{Y} 2$ of the Level 1 testing, the interest cover (EBIT/TA) increases from the ratio of 264 in Y1 to 14210 in Y2. Consistency is always good; however, abnormal decreases and increases should draw attention, especially if it is the way above the norm or standard. The norm or standard in this study has been indicated as five times. The ratio in $\mathrm{Y} 1$ is 58 times higher, whilst in Y2, it is 2842 times higher. Upon further

TABLE 3: Howden Africa Holding Ltd.

\begin{tabular}{lccccccc}
\hline Ratio & Definition & Coefficient & \multicolumn{5}{c}{ HWN } \\
\cline { 3 - 8 } & & & Y5 & Y4 & Y3 & Y2 & Y1 \\
\hline- & - & 3.25 & - & - & - & - & - \\
X1 & WC/TA & 6.56 & 0.67 & 0.63 & 0.6 & 0.52 & 0.35 \\
X2 & RE/TA & 3.26 & 0.59 & 0.56 & 0.52 & 0.39 & 0.22 \\
X3 & EBIT/TA & 6.72 & 0.15 & 0.13 & 0.17 & 0.23 & 0.34 \\
X4 & BVE/TL & 1.05 & 2.57 & 2.07 & 1.91 & 1.35 & 0.75 \\
$z$-score & & - & 5.90 & 13.28 & 12.26 & 12.03 & 10.90 \\
Classification & - & Safe & Safe & Safe & Safe & Safe \\
\hline
\end{tabular}

Source: INET McGregor BFA., 2018, INET BFA database, INET BFA, viewed 14 Novembe 2019, from https://research.mcgregorbfa.com/Login.aspx?ReturnUrl=\%2fDefault.aspx

$\mathrm{WC} / \mathrm{TA}$, working capital to total assets; RE/TA, retained earnings to total assets; EBIT/TA, earnings before interest and tax to total assets; TE/TL, books value of equity to total liabilities; HWN, Howden Africa Holding Ltd.

TABLE 4: Howden Africa Holding Ltd.

\begin{tabular}{lcccccc}
\hline Testing level & Ratios & \multicolumn{5}{c}{ HWN } \\
\cline { 3 - 7 } & & Y5 & Y4 & Y3 & Y2 & Y1 \\
\hline Level 1: SOCI & ROE & 18.28 & 17.41 & 20.74 & 32.76 & 55.71 \\
& 18.76 & Below & Below & Above & Above & Above \\
& EBIT/TA & $2,180.41$ & $3,439.04$ & $9,814.30$ & $14,210.74$ & 264.05 \\
& $5 \times$ & Above & Above & Above & Above & Above \\
& ROA & 15.14 & 13.63 & 17.23 & 23.66 & 35.70 \\
& 13.91 & Above & Below & Above & Above & Above \\
Level 2: SFP & CF/TD & 55.71 & 39.33 & 25.84 & 60.66 & 44.49 \\
& 33.16 & Above & Above & Below & Above & Above \\
& TATO & 0.83 & 0.88 & 0.96 & 1.15 & 1.34 \\
& 1.90 & Below & Below & Below & Below & Below \\
\hline
\end{tabular}

Source: INET McGregor BFA., 2018, INET BFA database, INET BFA, viewed 14 November 2019, from https://research.mcgregorbfa.com/Login.aspx?ReturnUrl=\%2fDefault.aspx

ROE, return on equity; ROA, return on assets; EBIT/TA, earnings before interest and tax to total assets; TATO, total asset turnover; CF/TD, cash flow to total debt; HWN, Howden Africa Holding Ltd.; SOCI, statement of comprehensive income; SFP, statement of financial position. 
investigation, it was revealed that from $\mathrm{Y} 1$ to $\mathrm{Y} 2$ sales decreased by $5.6 \%$, the cost of sales decreased by $4.6 \%$ and the total cost increased by $36 \%$. The following increases were noted: EBIT increase of $38 \%$ and interest increase of $30 \%$ caused by the $33 \%$ increase in long-term interest-bearing loans. Table 5 depicts the EMS model results of Edgars Consolidated Stores (ECO).

The EMS displayed in Table 5 echoes the safe zone from Y1 to Y5, which means that ECO has had a strong credit profile for the five consecutive years under review. In Table 6, the BPIA of Edgars Consolidated Stores is evaluated.

In Table 6, Level 1 testing is illustrated. ECO is displayed as financially fit three of the 5 years for the period under review (2002-2006) as this is the only financial statement data available on INET McGregor BFA. Return on equity according to guidelines is presented as $\mathrm{Y} 1$ and $\mathrm{Y} 2$ below the safe level at 7.48 and 15.88 , respectively. In $\mathrm{Y} 3-\mathrm{Y} 5$, it is above the safe level at 25.52, in $Y 4$ at 35.89 and in $Y 5$ at 37.44. Interest cover $5 \times$ is referred to as being a successful company according to the literature. ECO is based on the literature successful for Y2-Y5. In Y1, below the safe level of $5 \times$, in $\mathrm{Y} 2-\mathrm{Y} 5$, lowest at $7.35 \times$ in $\mathrm{Y} 2$ and highest at 67.67 in $\mathrm{Y} 5$. Return on assets is below the safe level at 7.83 in $\mathrm{Y} 1$ and thereafter above in $\mathrm{Y} 2-\mathrm{Y} 5$. Due to no financial distress detected Level 2 testing there was no interruptions

TABLE 5: Edgars Consolidated Stores Ltd.

\begin{tabular}{lccccccc}
\hline Ratio & Definition & Coefficient & \multicolumn{7}{c}{ ECO } \\
\cline { 3 - 7 } & & & Y5 & Y4 & Y3 & Y2 & Y1 \\
\hline- & - & 3.25 & - & - & - & - & - \\
X1 & WC/TA & 6.56 & 0.23 & 0.29 & 0.3 & 0.22 & 0.42 \\
X2 & RE/TA & 3.26 & 0.37 & 0.38 & 0.4 & 0.42 & 0.4 \\
X3 & EBIT/TA & 6.72 & 0.26 & 0.27 & 0.21 & 0.14 & 0.08 \\
X4 & BVE/TL & 1.05 & 1.02 & 1.09 & 1.08 & 1.05 & 1.24 \\
$z$-score & & - & 8.78 & 9.35 & 9.07 & 8.11 & 9.15 \\
Classification & - & Safe & Safe & Safe & Safe & Safe \\
\hline
\end{tabular}

Source: INET McGregor BFA., 2018, INET BFA database, INET BFA, viewed 14 Novembe 2019, from https://research.mcgregorbfa.com/Login.aspx?ReturnUrl=\%2fDefault.aspx

WC/TA, working capital to total assets; RE/TA, retained earnings to total assets; EBIT/TA earnings before interest and tax to total assets; TE/TL, books value of equity to total liabilities; ECO, Edgars Consolidated Stores Ltd.

TABLE 6: Edgars Consolidated Stores Ltd

\begin{tabular}{lcccccc}
\hline Testing level & Ratios & \multicolumn{5}{c}{ ECO } \\
\cline { 3 - 7 } & & Y5 & Y4 & Y3 & Y2 & Y1 \\
\hline Level 1: SOCI & ROE & 37.44 & 35.89 & 25.52 & 15.88 & 7.48 \\
& 18.76 & Above & Above & Above & Below & Below \\
& EBIT/TA & 52.67 & 67.67 & 23.07 & 7.34 & 4.50 \\
& $5 \times$ & Above & Above & Above & Above & Below \\
& ROA & 25.94 & 27.81 & 21.05 & 14.61 & 7.83 \\
& 13.91 & Above & Above & Above & Above & Below \\
Level 2: SFP & CF/TD & 33.57 & 49.79 & 8.53 & 35.59 & 36.46 \\
& 33.16 & Above & Above & Below & Above & Above \\
& TATO & 2.06 & 2.07 & 2.28 & 2.21 & 1.78 \\
& 1.90 & Above & Above & Above & Above & Below \\
\hline
\end{tabular}

Source: INET McGregor BFA., 2018, INET BFA database, INET BFA, viewed 14 November 2019, from https://research.mcgregorbfa.com/Login.aspx?ReturnUrl=\%2fDefault.aspx

ROE, return on equity; ROA, return on assets; $E B I T / T A$, earnings before interest and tax to total assets; TATO, total asset turnover; CF/TD, cash flow to total debt; ECO, Edgars Consolidated Stores Ltd.; SOCI, statement of comprehensive income; SFP, statement of financial position. caused by financial distress detected CF/TD the cash flow from operations: in $\mathrm{Y} 1-\mathrm{Y} 2$, there was a $21 \%$ increase; in $\mathrm{Y} 2-\mathrm{Y} 3$, it declined by $25 \%$; in $\mathrm{Y} 3-\mathrm{Y} 4$, the cash flow from operations increased three times more than in $\mathrm{Y} 3$ cash flow from operation; and in $Y 5$, it resulted with a 70\% drop. The CF/TD ratio indicates the company's ability to cover the total debt using cash flow. The total asset turnover even though positive was below the safe level in Y1, and thereafter, the ratios were above the safe level from $\mathrm{Y} 2$ to Y5. The EMS model of Basil Read Holdings is shown in Table 7.

BSR's EMS indicated in Y1, Y3 and Y4 is within the safe zone (strong credit profile) as shown in Table 7 . The grey zone indicates adequate credit policy in Y2. The distress zone indicating extremely high risk in $\mathrm{Y} 5$ points towards a concern how within a year BSR financial status is able to move from grey to safe for 2 years, then suddenly within the distress zone being an extreme high risk. In $Y 2$, variables $\mathrm{x} 1$ and $\mathrm{x} 3$ were negative, $\mathrm{x} 1(0.1)$ and $\mathrm{x} 3(0.21) . \mathrm{x} 1$ represents $\mathrm{WC} / \mathrm{TA}$ and $\mathrm{x} 3$ is EBIT/TA. In Y2, WC decreased by $82 \%$ and total debt decreased by $9 \%$, whilst EBIT declined by $17 \%$. The EMS for BSR was within the distress zone in Y5 and further investigation pointed to $x 1(0.21)$ and $x 3(0.27)$ variables. The decline was because of both negative WC and EBIT. Next, the BPIA of Basil Read Holdings is displayed in Table 8.

TABLE 7: Basil Read Holding Ltd

\begin{tabular}{lccccccc}
\hline Ratio & Definition & Coefficient & \multicolumn{5}{c}{ BSR } \\
\cline { 3 - 8 } & & & Y5 & Y4 & Y3 & Y2 & Y1 \\
\hline X1 & WC/TA & 6.25 & - & - & - & - & - \\
X2 & RE/TA & 3.26 & 0.03 & 0.05 & 0.02 & 0.2 & 0.16 \\
X3 & EBIT/TA & 6.72 & -0.27 & 0.02 & 0.06 & -0.21 & 0.02 \\
X4 & BVE/TL & 1.05 & 0.04 & 0.53 & 0.51 & 0.32 & 0.66 \\
$z$-score & & - & -0.13 & 4.30 & 3.99 & 2.17 & 4.99 \\
Classification & - & Distress & Safe & Safe & Grey & Safe \\
\hline
\end{tabular}

Source: INET McGregor BFA., 2018, INET BFA database, INET BFA, viewed 14 November 2019, from https://research.mcgregorbfa.com/Login.aspx?ReturnUrl=\%2fDefault.aspx

WC/TA, working capital to total assets; RE/TA, retained earnings to total assets; EBIT/TA, earnings before interest and tax to total assets; TE/TL, books value of equity to total liabilities; BSR, Basil Read Holding Ltd.

TABLE 8: Basil Read Holding Ltd.

\begin{tabular}{lcccccc}
\hline Testing level & Ratios & \multicolumn{5}{c}{ BSR } \\
\cline { 3 - 7 } & & Y5 & Y4 & Y3 & Y2 & Y1 \\
\hline Level 1: SOCI & ROE & -908.20 & -5.62 & 14.51 & -69.69 & 16.27 \\
& 18.76 & Below & Below & Below & Below & Below \\
& EBIT/TA & -7.92 & 1.09 & 4.63 & -16.45 & 1.54 \\
& $5 \times$ & Below & Below & Below & Below & Below \\
& ROA & -26.59 & 1.72 & 6.13 & -21.72 & 2.33 \\
& 13.91 & Below & Below & Below & Below & Below \\
Level 2: SFP & CF:TD & -15.21 & 2.16 & -5.21 & -4.06 & 7.61 \\
& 33.16 & Below & Below & Below & Below & Below \\
& TATO & 1.67 & 1.61 & 1.59 & 1.58 & 1.46 \\
& 1.90 & Below & Below & Below & Below & Below \\
\hline
\end{tabular}

Source: INET McGregor BFA., 2018, INET BFA database, INET BFA, viewed 14 November 2019, from https://research.mcgregorbfa.com/Login.aspx?ReturnUrl=\%2fDefault.aspx

ROE, return on equity; ROA, return on assets; EBIT/TA, earnings before interest and tax to total assets; TATO, total asset turnover; CF/TD, cash flow to total debt; EBIT/TA, earnings before interest and tax to total assets; BSR, Basil Read Holding Ltd.; SOCI, statement of comprehensive income; SFP, statement of financial position. 
The bankruptcy indicators shown in Table 8 give a clear sign of financial distress for the full period under review. The ROE reflects a high negative in Y2 (69.69) and in Y5 (908.20) indicating that the company uses this is a revelation that the company does use the shareholders' / owners' funds to generate profits; instead, this negative could indicate losses, and therefore, the ratio is negative. The interest cover is also negative (16.45), reflecting the company's inability to repay its interest obligations. Finally, on the Level 1 testing, ROA is also at a negative high of 21.72 in $Y 2$ and 26.59 in Y5. Level 2 testing CF/TD is negative in Y2, Y3 and Y5 and TATO, even though positive still below the safe level for the period under review. In Table 9, the EMS model of Steinhoff International Holding is evaluated.

Steinhoff's EMS model classification as shown in Table 9 is safe over the 5-year period under review. The $z$-score increases from $\mathrm{Y} 1$ to $\mathrm{Y} 3$, with a slight decline in $\mathrm{Y} 4$ and another increase from Y4 to Y5. The BPIA for Steinhoff International Holding is displayed in Table 10.

Table 10 shows that bankruptcy indicators (ROE) fluctuated from $\mathrm{Y} 1$ to $\mathrm{Y} 5$ but below the safe level for the 5 years under assessment. The interest cover (EBIT/TA) remained below the $5 \times$ safe level throughout the period under review. Return on assets also remained below the safe level. Level 2 testing CF/TD increased every year, except for the $45 \%$ decrease in the ratio from $\mathrm{Y} 4$ to $\mathrm{Y} 5$, yet below the safe level mark.

TABLE 9: Steinhoff International Holding Ltd.

\begin{tabular}{lccccccc}
\hline Ratio & Definition & Coefficient & \multicolumn{7}{c}{ SNH } \\
\cline { 3 - 8 } & & & Y5 & Y4 & Y3 & Y2 & Y1 \\
\hline- & - & 3.25 & - & - & - & - & - \\
X1 & WC/TA & 6.56 & 0.06 & 0.11 & 0.07 & 0.06 & 0.06 \\
X2 & RE/TA & 3.26 & 0.16 & 0.15 & 0.18 & 0.18 & 0.18 \\
X3 & EBIT/TA & 6.72 & 0.06 & 0.06 & 0.07 & 0.07 & 0.06 \\
X4 & BVE/TL & 1.05 & 0.98 & 1.39 & 0.77 & 0.68 & 0.68 \\
$z$-score & - & 5.90 & 5.60 & 6.32 & 5.57 & 5.41 \\
Classification & - & Safe & Safe & Safe & Safe & Safe \\
\hline SOurce & & & & & & &
\end{tabular}

Source: INET McGregor BFA., 2018, INET BFA database, INET BFA, viewed 14 Novembe 2019, from https://research.mcgregorbfa.com/Login.aspx?ReturnUrl=\%2fDefault.aspx

WC/TA, working capital to total assets; RE/TA, retained earnings to total assets; EBIT/TA earnings before interest and tax to total assets; TE/TL, books value of equity to total liabilities; SNH, Steinhoff International Holding Ltd.

TABLE 10: Steinhoff International Holding Ltd.

\begin{tabular}{lcccccc}
\hline Testing level & Ratios & \multicolumn{5}{c}{ SNH } \\
\cline { 3 - 7 } & & Y5 & Y4 & Y3 & Y2 & Y1 \\
\hline Level 1: SOCI & ROE & 9.75 & 7.41 & 11.99 & 12.39 & 12.26 \\
& 18.76 & Below & Below & Below & Below & Below \\
& EBIT/TA & 4.05 & 4.65 & 4.05 & 3.36 & 3.15 \\
& $5 x$ & Below & Below & Below & Below & Below \\
& ROA & 12.18 & 9.99 & 10.37 & 10.52 & 9.46 \\
& 13.91 & Below & Below & Below & Below & Below \\
Level 2: SFP & CF:TD & 12.10 & 22.05 & 18.27 & 13.26 & 12.04 \\
& 33.16 & Below & Below & Below & Below & Below \\
& TATO & 1.12 & 0.77 & 1.00 & 1.11 & 0.96 \\
& 1.90 & Below & Below & Below & Below & Below \\
\hline
\end{tabular}

Source: INET McGregor BFA., 2018, INET BFA database, INET BFA, viewed 14 November 2019, from https://research.mcgregorbfa.com/Login.aspx?ReturnUrl=\%2fDefault.aspx

ROE, return on equity; ROA, return on assets; EBIT/TA, earnings before interest and tax to total assets; TATO, total asset turnover; CF/TD, cash flow to total deb; SNH, Steinhof International Holding Ltd.; SOCI, statement of comprehensive income; SFP, statement of financial position.
The TATO ratio indicates how efficient a company uses its assets. A low ratio indicates that they are not used efficiently and could affect company's productivity. For all 5 years under investigation, the TATO ratio was below the safe level mark. Group Five Holding EMS evaluation is shown in Table 11.

Emerging market scores according to Table 11 are situated within the safe zone successively for the 5 years under review. Next, the BPIA of Group Five Holdings is shown in Table 12.

Table 12 indicates that the BPIA in Y1-Y5 for GHO Level one testing is alarming as all the ratios ROE, (EBIT/TA) and ROA are below the safe level for the 5 year being investigated. It is an indication that the company is not generating profit from shareholders/owners' funds nor it is able to repay their interest obligations. It also shows that the company is not utilising its assets effectively and efficiently. The second-level testing also reflects the company's inability to cover the total debt with its cash flow. The TATO is above the safe level marks at 1.95 in Y1 and 1.92 in $\mathrm{Y} 3$.

\section{Summary and conclusion}

The main objective of this study was to assess the effectiveness of the BPIA by testing it on JSE companies that not necessarily

TABLE 11: Group Five Holding Ltd.

\begin{tabular}{lccccccc}
\hline Ratio & Definition & Coefficient & \multicolumn{7}{c}{ GHO } \\
\cline { 3 - 8 } & & & Y5 & Y4 & Y3 & Y2 & Y1 \\
\hline- & - & 3.25 & - & - & - & - & - \\
X1 & WC/TA & 6.56 & 0.01 & 0.03 & 0.01 & 0.03 & 0.07 \\
X2 & RE/TA & 3.26 & 0.03 & 0.02 & 0.02 & 0.03 & 0.03 \\
X3 & EBIT/TA & 6.72 & 0.03 & 0.05 & 0.06 & 0.04 & 0.07 \\
X4 & BVE/TL & 1.05 & 0.41 & 0.45 & 0.37 & 0.38 & 0.4 \\
$z$-score & & - & 4.05 & 4.32 & 4.17 & 4.21 & 4.70 \\
Classification & - & Safe & Safe & Safe & Safe & Safe \\
\hline
\end{tabular}

Source: INET McGregor BFA., 2018, INET BFA database, INET BFA, viewed 14 November 2019, from https://research.mcgregorbfa.com/Login.aspx?ReturnUrl=\%2fDefault.aspx WC/TA, working capital to total assets; RE/TA, retained earnings to total assets; EBIT/TA, earnings before interest and tax to total assets; TE/TL, books value of equity to total liabilities; GHO, Group Five Holding Ltd.; SOCl, statement of comprehensive income; SFP, statement of financial position.

TABLE 12: Group Five Holding Ltd.

\begin{tabular}{lcccccc}
\hline Testing level & Ratios & \multicolumn{5}{c}{ GHO } \\
\cline { 3 - 7 } & & Y5 & Y4 & Y3 & Y2 & Y1 \\
\hline Level 1: SOCI & ROE & 5.59 & 12.61 & 9.70 & -0.94 & 16.27 \\
& 18.76 & Below & Below & Below & Below & Below \\
& EBIT/TA & 1.25 & 1.71 & 1.81 & 2.18 & 3.00 \\
& $5 x$ & Below & Below & Below & Below & Below \\
& ROA & 2.51 & 5.42 & 6.09 & 4.05 & 6.85 \\
& 13.91 & Below & Below & Below & Below & Below \\
Level 2: SFP & CF:TD & 0.77 & 7.70 & 6.20 & 19.17 & 19.58 \\
& 33.16 & Below & Below & Below & Below & Below \\
& TATO & 1.78 & 1.81 & 1.92 & 1.73 & 1.95 \\
& 1.90 & Below & Below & Above & Below & Above \\
\hline
\end{tabular}

Source: INET McGregor BFA., 2018, INET BFA database, INET BFA, viewed 14 November 2019, from https://research.mcgregorbfa.com/Login.aspx?ReturnUrl=\%2fDefault.aspx

ROE, return on equity; ROA, return on assets; EBIT/TA, earnings before interest and tax to total assets; TATO, total asset turnover; CF/TD, cash flow to total debt; GHO, Group Five

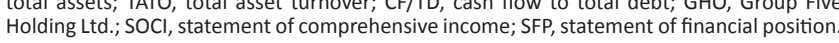


failed but are facing financial difficulties. The study adopted two models, namely the BPIA, a newly developed model from the South African perspective, and the Altman EMS model, which was modified with the aim of evaluating the financial distress of non-manufacturers and companies in emerging markets and successfully applied by Akbulayev, Guliyeva and Aslanova (2020) in Turkey, by Kristianto and Rikumahu (2019) in Indonesia and by Ngwenya (2018) in South Africa. The EMS model was used to substantiate the results of the BPIA.

Previous research has indicated that the EMS model is a renowned bankruptcy prediction model. The strength of the EMS model is that it is internationally recognised within the field of bankruptcy prediction of companies within emerging markets. Whilst its weakness is that three of the four variables (financial ratio) have a denominator of TAs when financial element or line items are intentionally or unintentionally misclassified. The misclassification could lead to misleading or corrupted results. The findings of this study are in agreement with the study by Cassim (2015:206), 'the EMS model is not as successful in a South African context'. Based on the results obtained, it is evident that the BPIA has a better prediction accuracy than the EMS within a South African context. Empirical results of the underlying sample indicated that the EMS model revealed that four of the five companies $(80 \%)$ were within the safe zone for the 5 -year period and one of the five companies were in the safe zone in $Y 1$, in the grey uncertainty zone in $\mathrm{Y} 2$, in $\mathrm{Y} 3$ and $\mathrm{Y} 4$ in the safe zone and in the distress zone in Y5, 1 year prior to failure. Whilst the BPIA indicated that one of the five companies revealed signs of failure or concerns in $\mathrm{Y} 4$ and $\mathrm{Y} 5$ and that four of the five companies $(80 \%)$ showed signs of trouble in $\mathrm{Y} 1$ :

- Howden African (Industrial Sector): EMS showed no signs of financial concern, whilst BPIA indicated concern in $Y 4$ and $Y 5$.

- Edgars Consolidates Stores (Retails Sector): EMS showed no signs of concern for BPIA in Y1 but there after improved giving no rise to any financial concern.

- Basil Read Holding (Construction Sector): EMS showed concern in Y2 and Y5 only, whereas BPIA revealed signs of concern for the period Y1-Y5.

- Steinhoff International Holding (Personal and Household Sector): EMS showed no signs of concern unlike BPIA that showed signs of financial distress for the period Y1-Y5.

- Group Five Holdings (Construction Sector): EMS with no financial concern is exposed in contrast to BPIA with Level 1 testing indicating financial distress from $\mathrm{Y} 1$ to $\mathrm{Y}$, except for TATO only above the safe level in Y1 and Y3.

Furthermore, the contribution of this study was to highlight that the BPIA is a prediction tool that is effective, efficient, easy to use and applied for either predicting or detecting failure 5 years prior to the occurrence of bankruptcy or financial distress. Therefore, it is recommended that management regularly apply the BPIA in order to implement timely turnaround strategies by taking corrective actions where necessary to improve the financial health of the company or create effective timely financial buffers.

Finally, there is a clear need to consider adding non-financial factors to the model to improve prediction accuracy. Further studies could be conducted to develop a bankruptcy prediction model that includes non-financial factors and overcomes the historical weakness of solely relying on financial factors only, which can be manipulated. Thus, a tool is useful and necessary for a company to be protected against failure.

\section{Acknowledgements}

The authors would like to acknowledge Elizabeth Bothma for supporting with data analysis.

\section{Competing interests}

The authors have declared that no competing interest exists.

\section{Authors' contributions}

All authors contributed equally to this work.

\section{Funding information}

This research received funding from the North-West University.

\section{Data availability statement}

The authors confirm that the data supporting the findings of this study are available within the article.

\section{Disclaimer}

The views and opinions expressed in this article are those of the authors and do not necessarily reflect the official policy or position of any affiliated agency of the authors.

\section{References}

Akbulayev, N., Guliyeva, N. \& Aslanova, G., 2020, 'Economic analysis of tourism enterprise solvency and the possibility of bankruptcy: The case of the Thomas cook group', African Journal of Hospitality, Tourism and Leisure 9(2), 1-12.

Altman, E.I., 1968, 'Financial ratios, discriminant analysis and the prediction of corporate bankruptcy', The Journal of Finance 23(4), 589-609. https://doi. org/10.1111/j.1540-6261.1968.tb00843.x

Altman, E.I., 1993, Corporate financial distress and bankruptcy: A complete guide to predicting and avoiding distress and profiting from bankruptcy, 2 nd edn., John Wiley \& Sons, New York, NY.

Altman, E.I., 2002, 'The use of credit scoring models and the importance of a credit culture', linha, viewed 15 September 2011, from https://people.stern.nyu.edu/ ealtman/Presentations.html.

Altman, E.I. \& Hotchkiss, E., 2010, Corporate financial distress and bankruptcy: Predict and avoid bankruptcy, analyze and invest in distressed debt, vol. 289. John Wiley $\&$ Sons, New York, NY.

Asuelime, L.E., 2018, 'The pros of South Africa's membership of BRICS', Journal of African Union Studies 7(1), 129-150. https://doi.org/10.31920/2050-4306/2018/v7n1a7

Beaver, W., 1966, 'Financial ratios as predicators of failure, empirical research in accounting: Selected studies', Journal of Accounting Research 5, 1-25. https://doi. org/10.2307/2490171

Beaver, W.H., McNichols, M.F. \& Rhie, J.W., 2005, 'Have financial statements become less informative? Evidence from the ability of financial ratios to predict bankruptcy', Review of Accounting studies 10(1), 93-122. https://doi.org/10.1007/ s11142-004-6341-9 
Bellovary, J.L., Giacomino, D.E. \& Akers, M.D., 2007, 'A review of bankruptcy prediction studies: 1930 to present', Journal of Financial Education 33(Winter), 1-42.

Bless, C., Higson-Smith, C. \& Kagee, A., 2013, Fundamentals of social research methods: An African perspective, Juta \& Company (Pty) Ltd., Cape Town.

Cassim, R.J., 2015, 'The value of financial ratio analysis in predicting the failure of JSE listed companies', Master's thesis, Accountancy, North-West University.

Cassim, R.J., 2020, 'Development and validation of bankruptcy prediction indicators on JSE listed companies', PhD dissertation, Accountancy, North-West University.

Charitou, A., Neophytou, E. \& Charalambous, C., 2004, 'Predicting corporate failure: Empirical evidence for the UK', European Accounting Review 13(3), 465-497. https://doi.org/10.1080/0963818042000216811

Ciampi, F., 2015, 'Corporate governance characteristics and default prediction modeling for small enterprises. An empirical analysis of Italian firms', Journal of Business Research 68(5), 1012-1025. https://doi.org/10.1016/j.jbusres.2014.10.003

Coelho, M., 2014, 'Predicting corporate failure: An application of Altman's z-score and Altman's EMS models to the JSE alternative exchange from 2008 to 2012', Master's thesis, Finance and Tax management, University of Cape Town, Cape Town.

Correia, C., Flynn, D., Uliana, E. \& Wormald, M., 2015, Financial management, Juta and Company Ltd, Cape Town.

Creswell, J.W., 2014, A concise introduction to mixed methods research. SAGE publications, SAGE, Los Angeles, CA.

Garelli, S., 2016, Why you will probably live longer than most big companies, IMD, Lausanne.

Gouws, D.G. \& Lucouw, P., 1999, 'The process beyond the numbers and ratios', Meditari Accountancy Research 7(1), 99-122.

Harmse, L.H., 2017, 'A comparison of the capital structures of the top 40 multinationa entities and the top 40 JSE-listed entities', The International Journal of Social Sciences and Humanity Studies 9(1), 121-135.

Hlahla, B.F., 2010, 'Assessing corporate financial distress in South Africa', Master's thesis, Commercial Law and Management, University of the Witwatersrand, Johannesburg.

Houghton, K.A. \& Woodliff, D.R., 1987, 'Financial ratios: The prediction of corporate 'success' and failure', Journal of Business Finance \& Accounting 14(4), 537-554. https://doi.org/10.1111/j.1468-5957.1987.tb00111.x

INET McGregor BFA., 2018, INET BFA database, INET BFA, viewed 14 November 2019, from https://research.mcgregorbfa.com/Login.aspx?ReturnUrl=\%2fDefault.aspx.

Kristianto, H. \& Rikumahu, B., 2019, 'A cross model telco industry financial distress prediction in Indonesia: Multiple discriminant analysis, logit and artificial neura network' in 20197 th international conference on information and communication technology (ICOICT) . IEEE, Kuala Lumpur, Malaysia, July 24-26, 2019, pp. $1-5$. https://doi.org/10.1109/IColCT.2019.8835198
Madrid-Guijarro, A., García-Pérez-de-Lema, D. \& Van Auken, H., 2011, 'An analysis of non-financial factors associated with financial distress', Entrepreneurship and Regional Development 23(3-4), 159-186. https://doi.org/10.1080/08985620 Regional

Maree, K., 2020, First steps in research, Van Schaik Publishers, Pretoria.

Mouton, J., 2011, How to succeed in your master's and doctoral studies: A South African guide and resource book, Van Schaik, Pretoria.

Ngwenya, S., 2018, 'Assessing the state of financial distress of listed gold and platinum mining companies in South Africa', Acta Universitatis Danubius, CEconomica 14(4), 655-677.

Pallant, J., 2016, SPSS survival manual: A step by step guide to data analysis using IBM SPSS, McGraw-Hill, Berkshire.

Purves, N. \& Niblock, S.J., 2018, 'Predictors of corporate survival in the US and Australia: An exploratory case study', Journal of Strategy and Management 11(3), 351-370. https://doi.org/10.1108/JSMA-06-2017-0044

Rama, K.D., 2012, 'An empirical evaluation of the Altman (1968) failure prediction model on South African JSE listed companies', Master's thesis, Department of Commerce, University of the Witwatersrand, Johannesburg.

Russell, L.A., Langemeier, M.R. \& Briggeman, B.C., 2013, 'The impact of liquidity and solvency on cost efficiency', Agricultural Finance Review 73(3), 413-425. https:// doi.org/10.1108/AFR-09-2012-0047

Sabela, S.W., Brummer, L.M., Hall, J.H. \& Wolmarans, H.P., 2018, ‘Using fundamental, market and macroeconomic variables to predict financial distress: A study of companies listed on the Johannesburg stock exchange', Journal of Economic and Financial Sciences 11(1), 1-11. https://doi.org/10.4102/jef v11i1.168

Saunders, W., 2016, 'Identifying the optimum ownership structure as a tax avoidance strategy of multinational entities: A JSE top 40 perspective', Doctoral dissertation, North-West University, Vaal Triangle Campus.

Schwester, R.W. (Ed.), 2015, Teaching research methods in public administration, IG Global, New York, NY.

Tuvadaratragool, S., 2013 'The role of financial ratios in signalling financial distress: Evidence from Thai listed companies', DBA (Department of Business Administration) theses, Southern Cross University, Lismore.

Vasantha, S., Vasantha, V. \& Thiayalnayaki, D., 2013, 'Prediction of business bankruptcy for selected Indian airline companies using Altman's model', International Journal of Research in Business Management 1(4), 19-26.

Zikmund, W.G., Carr, J.C. \& Griffin, M., 2013, Business research methods, Cengage Learning, Wadsworth. 